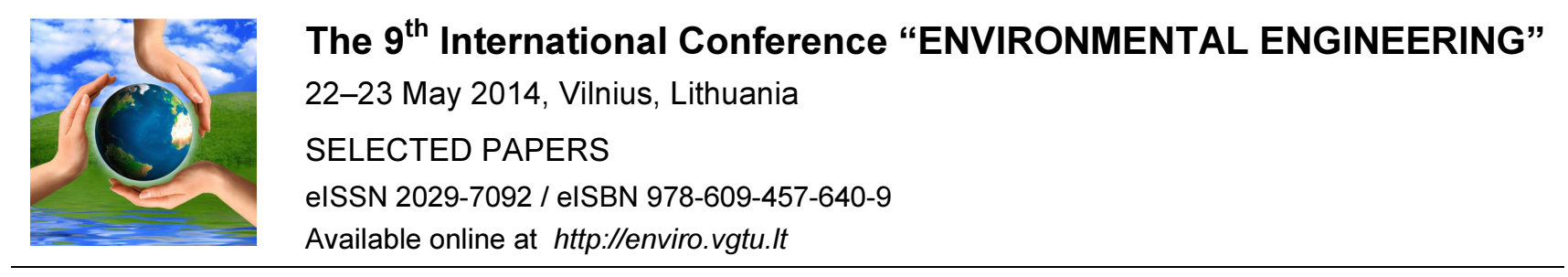

Section: Technologies of Geodesy and Cadastre

\title{
On evaluation of the digital terrain model generated from the LiDAR data of Lithuanian territory
}

\author{
Dominykas Šlikas, Aušra Kalantaitė, Boleslovas Krikštaponis, \\ Eimuntas Kazimieras Paršeliūnas, Rosita Birvydienè \\ Vilnius Gediminas Technical University, Sauletekio al. 11, 10223 Vilnius, Lithuania
}

\begin{abstract}
In 2008-2010 the LiDAR data were captured for all territory of Lithuania. According to the technical requirements, the density of the points approximately is 4 points in $1 \mathrm{sq}$. $\mathrm{m}$. This results in a very high resolution data set with a good spatial distribution. As was declared in technical requirements the accuracy of any LiDAR data point should be not worse than $15 \mathrm{~cm}$ in height component, and not worse than $30 \mathrm{~cm}$ in plane position. We were investigating the accuracy of the Digital Terrain Model, based on this LiDAR data set. The additional data of the first order vertical network points, gravity reference network points and geodetic reference network points were applied.
\end{abstract}

Keywords: LiDAR; Digital Terrain Model; normal height.

\section{Introduction}

Digital Terrain Models (DTMs) are the necessary requirement for the great number of applications. Existing DTMs are often not enough accurate, not detailed enough or too expensive [1, 2]. At present the LiDAR (Light Detection and Ranging) data is usually used to create the most reliable DTMs of countries territories [3-5]. The main reasons to apply LiDAR technology are the ability in short time to collect the big amount of information on Earth's surface points [6-12].

The accuracy of DTMs based on LiDAR information has reached a high level - till few centimeters in height component. Therefore some problem about the real accuracy is still exist. Published research results very often show pretty good results, which, from authors point of view, are too optimistic. In this paper we are presenting some results of investigations on the accuracy of DTM of Lithuanian territory.

\section{Experimental data}

In 2008-2010 the LiDAR data were captured for all territory of Lithuania. According to the technical requirements, the density of the points approximately is 4 points in $1 \mathrm{sq}$. $\mathrm{m}$. This results in a very high resolution data set with a good spatial distribution. As was declared in technical requirements the accuracy of any LiDAR data point should be not worse than $15 \mathrm{~cm}$ in height component, and not worse than $30 \mathrm{~cm}$ in plane position.

In 2012 these data were used to produce DTM of $1 \times 1 \mathrm{~m}$ resolution. Generation of DTM was done by a State enterprise „GIS Centras“. Let assign to this DTM a code DTM1 (Fig. 1).

Quality of elevation data is commonly expressed in terms of vertical accuracy. It can be determined using comparison data that should be based on accurate and independent methods, such as (terrestrial) topographic surveys, or photogrammetric techniques, allowing truly external and independent validation [5].

To evaluate the DTM of Lithuanian territory the following sets of geodetic data were used:

1. The normal heights of the Lithuanian first and second order geodetic vertical network points;

2. The normal heights of ground control points of orthophotomapping of Lithuanian territory;

3. The normal heights of Lithuanian State GPS network points.

Corresponding author: Dominykas Šlikas. E-mail address: dominykas.slikas@vgtu.lt

http://dx.doi.org/10.3846/enviro.2014.251

(C) 2014 The Authors. Published by VGTU Press. This is an open-access article distributed under the terms of the Creative Commons Attribution License, which permits unrestricted use, distribution, and reproduction in any medium, provided the original author and source are credited. 


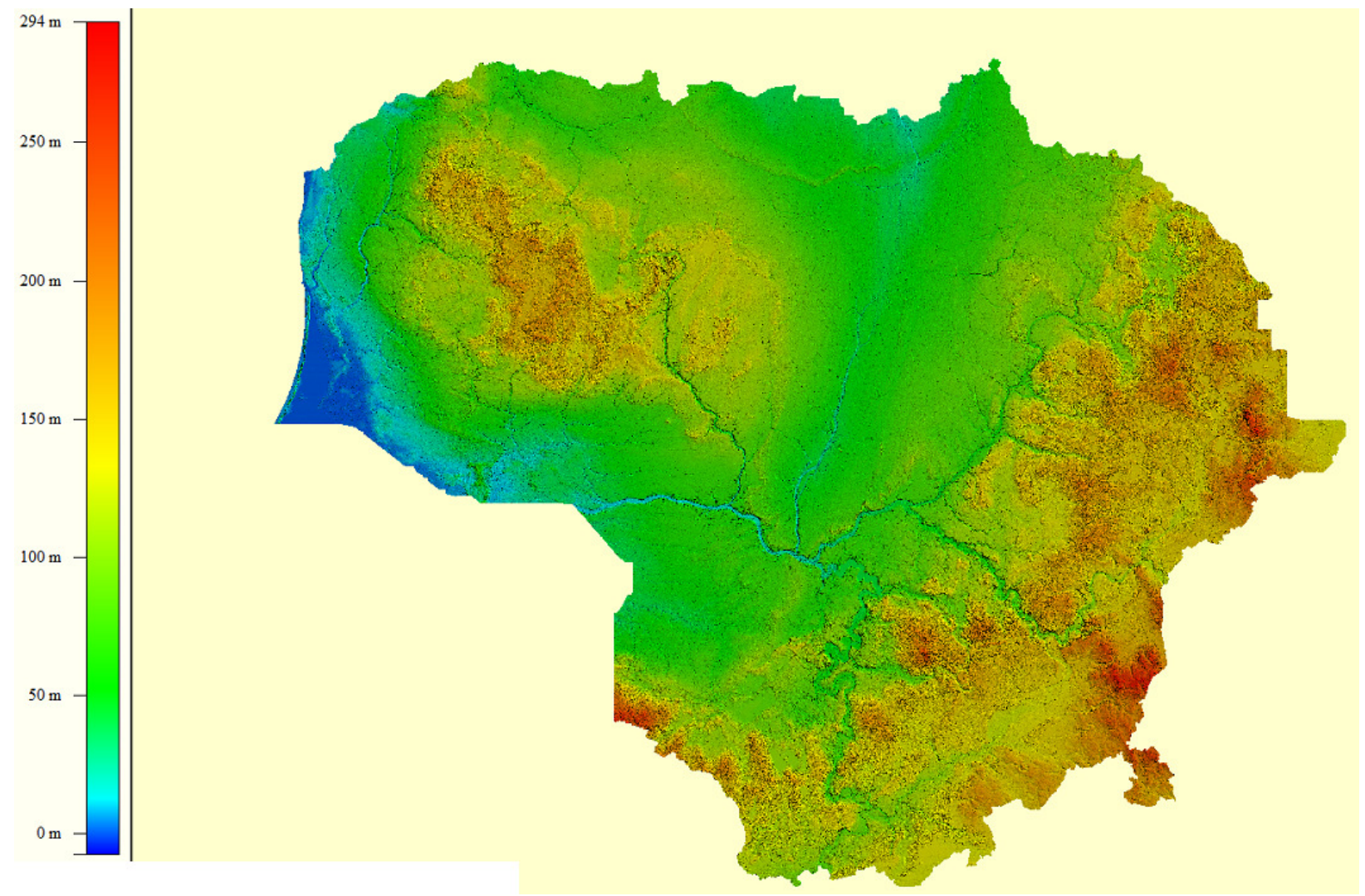

Fig. 1. Graphical view of DTM1 $(1 \times 1 \mathrm{~m})$

\section{DTM1 evaluation}

3.1. DTM1 evaluation against the normal heights of the Lithuanian first and second order geodetic vertical network points

The normal heights of the Lithuanian first and second order geodetic vertical network points were corrected by distances, measured from the point mark till ground surface. The normal heights of the points from the DTM1 were derived by two methods: ( 1 variant) by assigning the height value of a corresponding cell to a point or ( 2 variant) by the heights interpolation between nearest cells. The calculated differences of the ground truth normal heights and heights derived from DTM1 are presented in Figure 2 and 3.

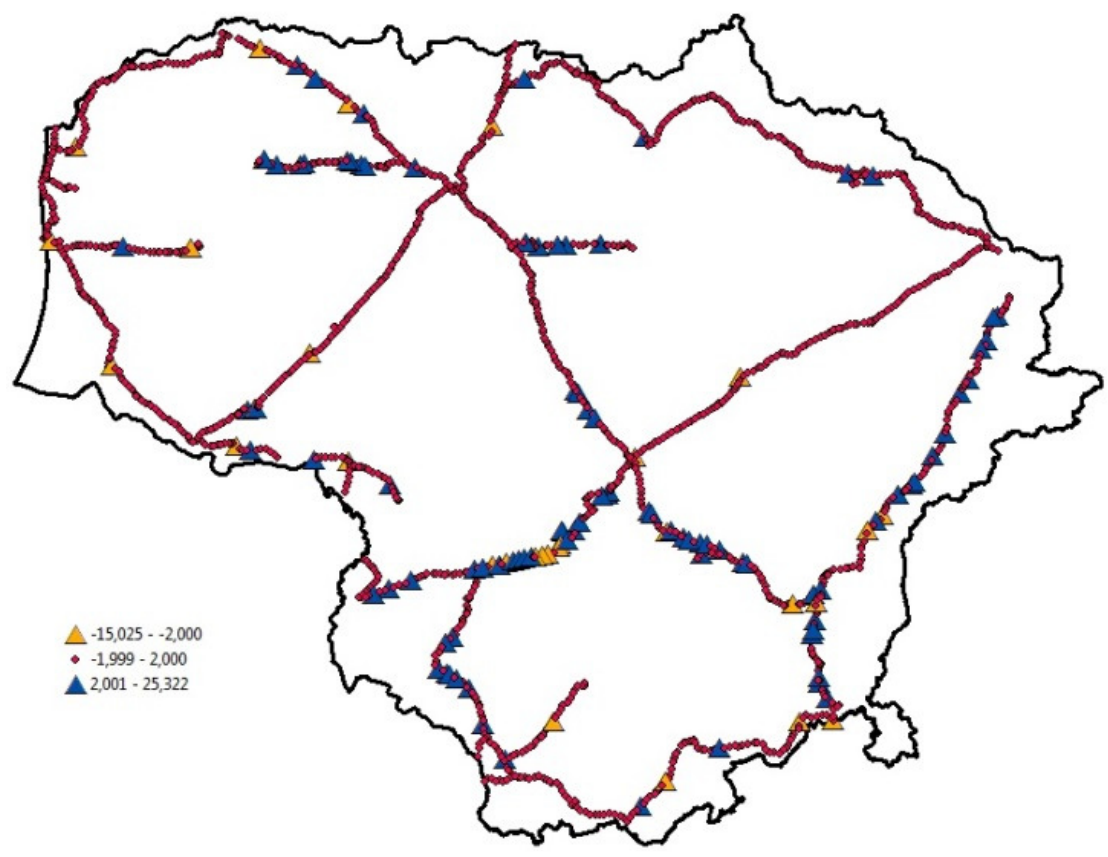

Fig. 2. Differences of normal heights at the Lithuanian first and second order geodetic vertical network points ( 1 variant) 


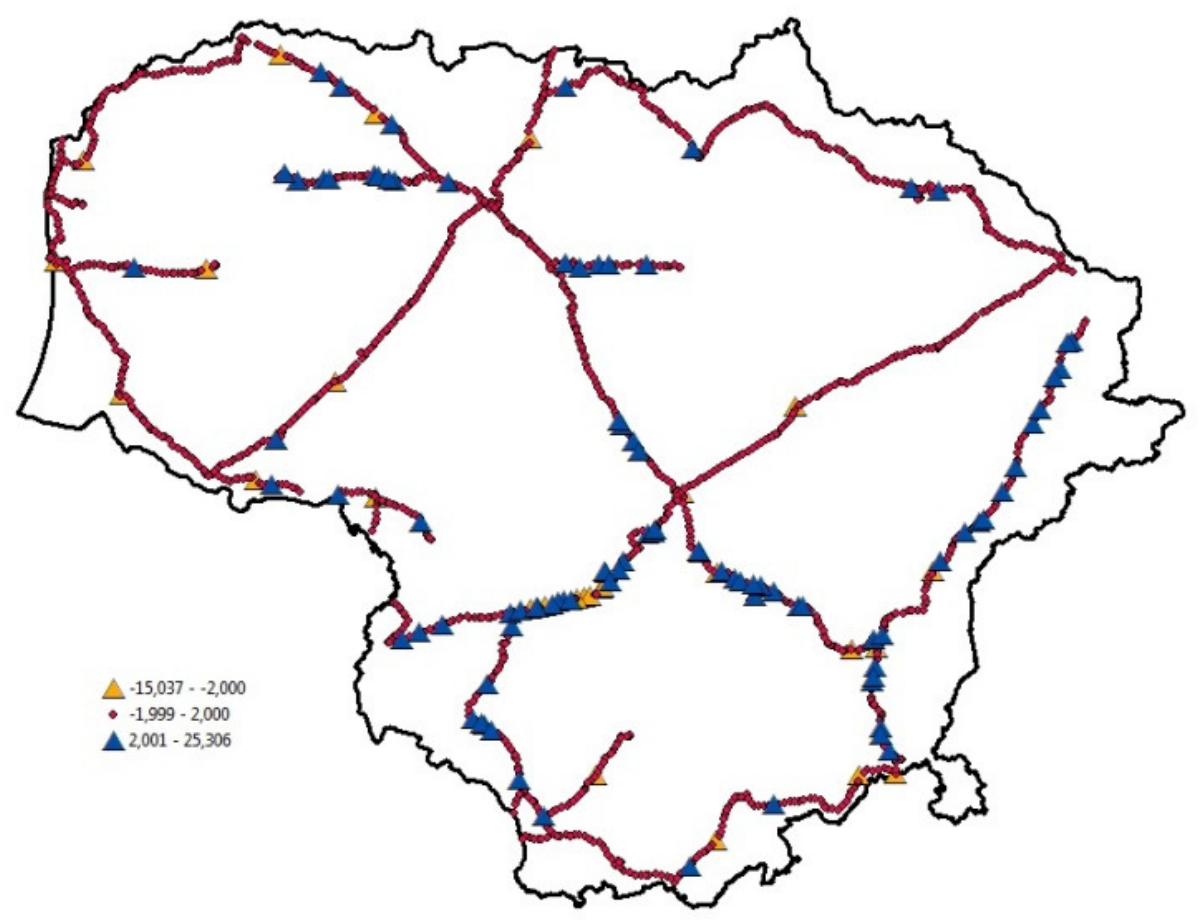

Fig. 3. Differences of normal heights at the Lithuanian first and second order geodetic vertical network points (2 variant)

We could accept that gross errors are bigger than $2 \mathrm{~m}$. We could eliminate points containing the gross errors and calculate final statistical parameters (Fig. 4 and Fig. 5 and Table 1).

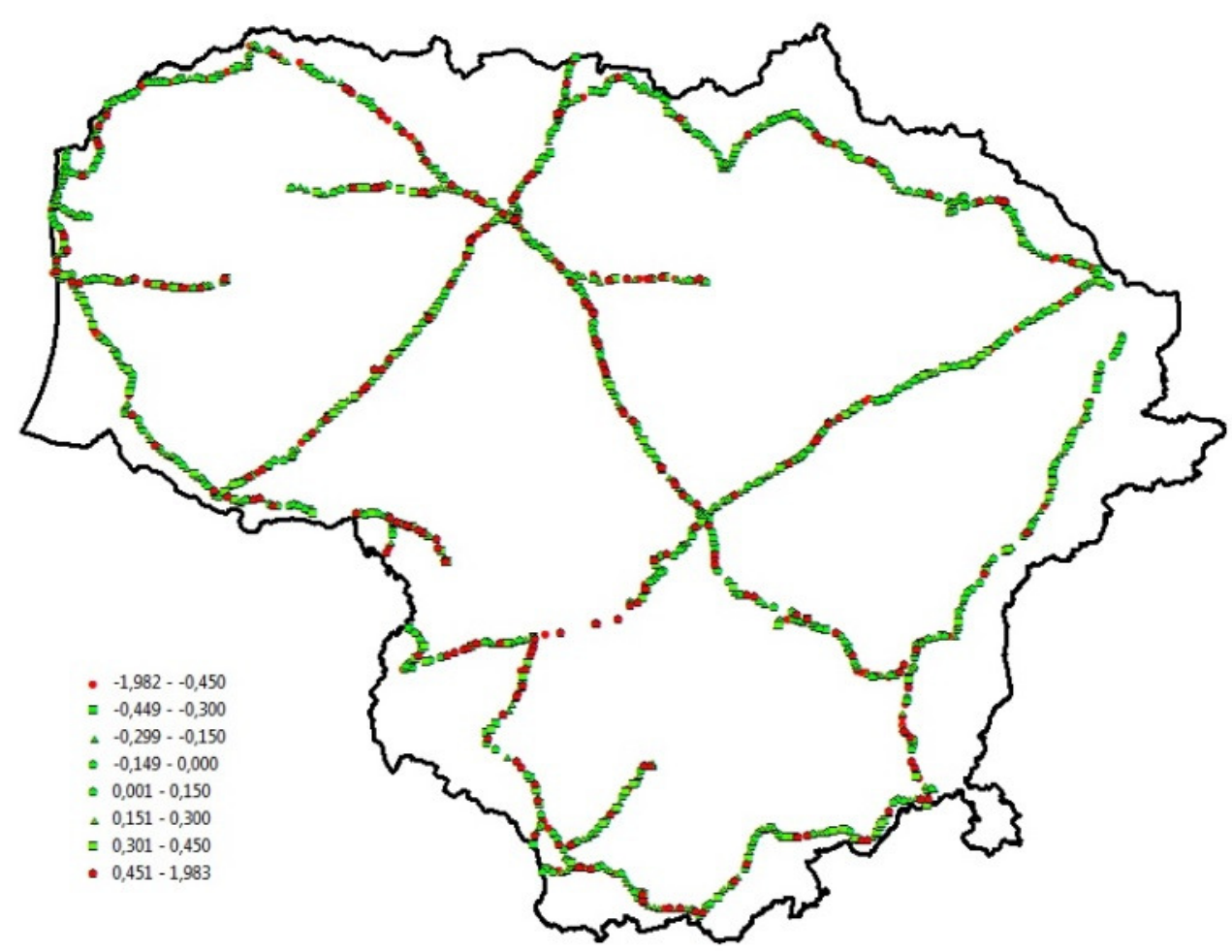

Fig. 4. Differences of normal heights at the Lithuanian first and second order geodetic vertical network points after elimination of gross errors (1 variant) 


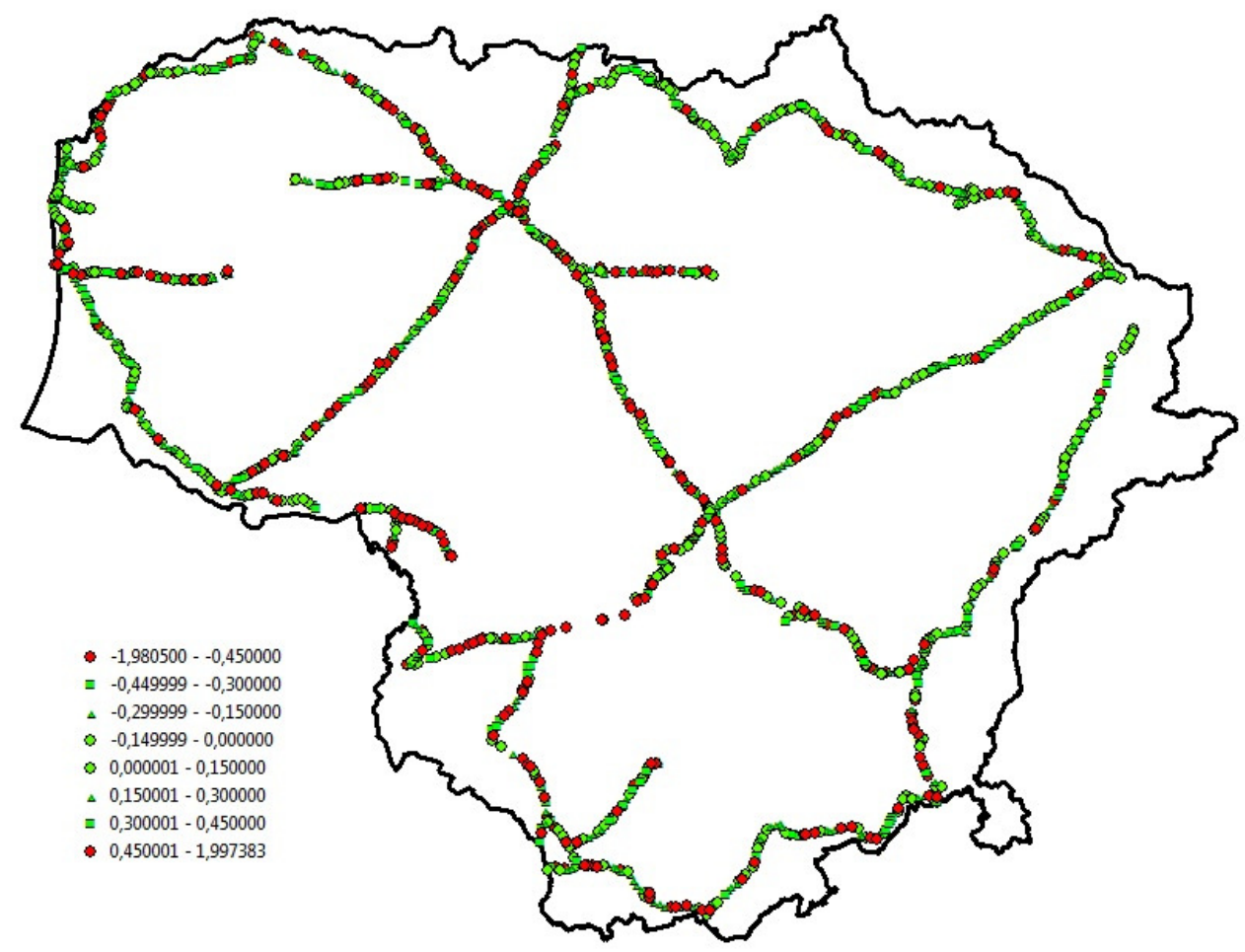

Fig. 5. Differences of normal heights at the Lithuanian first and second order geodetic vertical network points after elimination of gross errors (2 variant)

Table 1. DTM1 statistical parameters according to data of the Lithuanian first and second order geodetic vertical network points

\begin{tabular}{lcc}
\hline Statistical parameter & (1 variant) & (2 variant) \\
\hline Mean, $\mathrm{m}$ & 0.099 & 0.099 \\
Standard Error, $\mathrm{m}$ & 0.013 & 0.013 \\
Median, $\mathrm{m}$ & 0.082 & 0.080 \\
Mode, $\mathrm{m}$ & 0.095 & -0.097 \\
Standard Deviation, $\mathrm{m}$ & 0.496 & 0.502 \\
Sample Variance, $\mathrm{m}$ & 0.246 & 0.252 \\
Kurtosis, m & 3.356 & 3.470 \\
Skewness, $\mathrm{m}$ & 0.534 & 0.521 \\
Range, $\mathrm{m}$ & 3.965 & 3.978 \\
Minimum, m & -1.982 & -1.981 \\
Maximum, m & 1.983 & 1.997 \\
Sum, $\mathrm{m}$ & 139.440 & 139.927 \\
Number of points & 1407 & 1410 \\
Confidence Level(95.0\%), $\mathrm{m}$ & 0.026 & 0.026 \\
\hline
\end{tabular}

\subsection{DTM1 evaluation against the normal heights of ground control points of orthophotomapping of Lithuanian territory}

The normal heights of ground control points of orthophotomapping of Lithuanian territory are very suitable to evaluate the DTMs, because they are distributes evenly over the whole territory of a country, the normal heights are measured at the ground surface. The calculated differences of the ground truth normal heights and heights derived from DTM1 are presented in Figure 6 and Figure 7. 


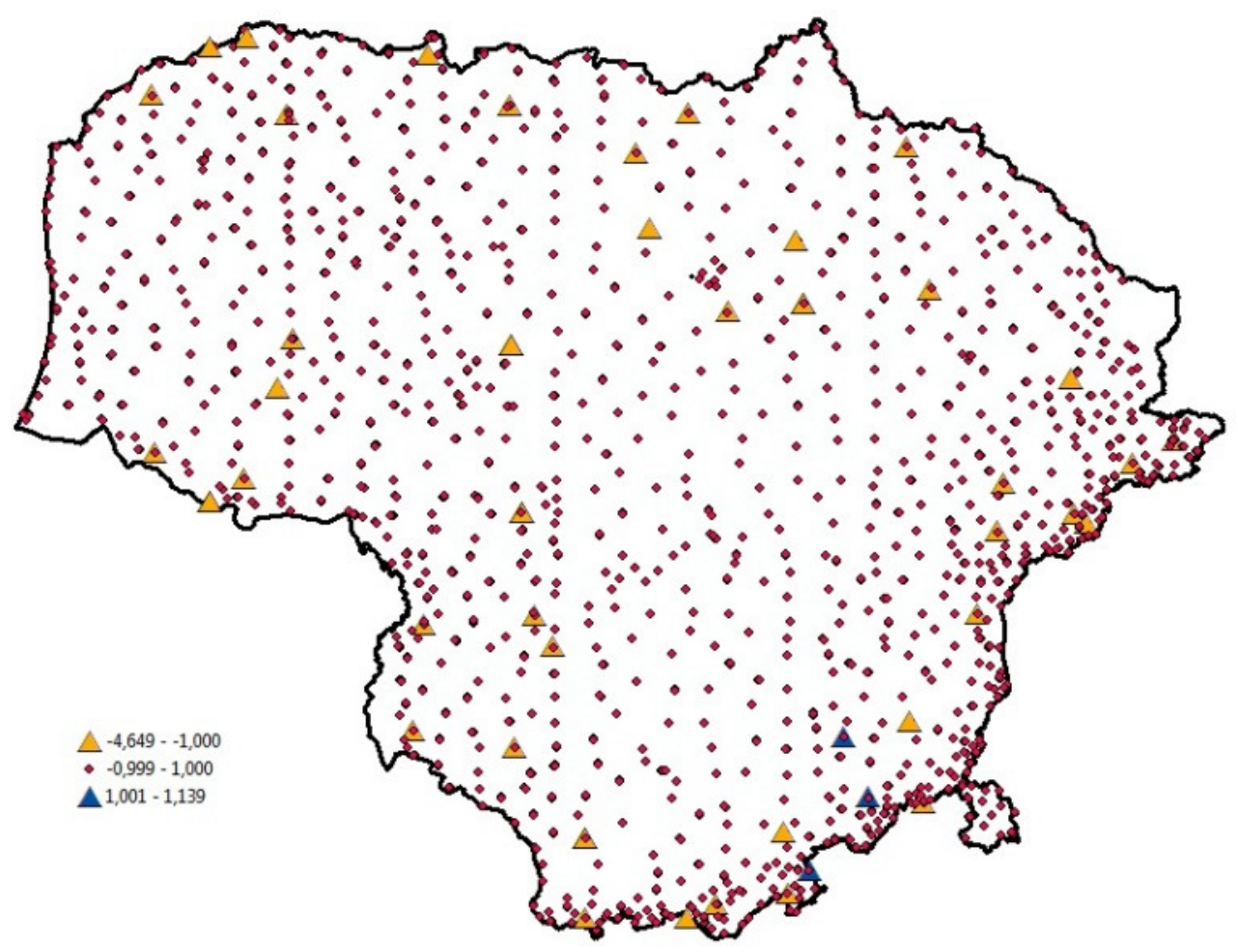

Fig. 6. Differences of normal heights at the ground control points (1 variant)

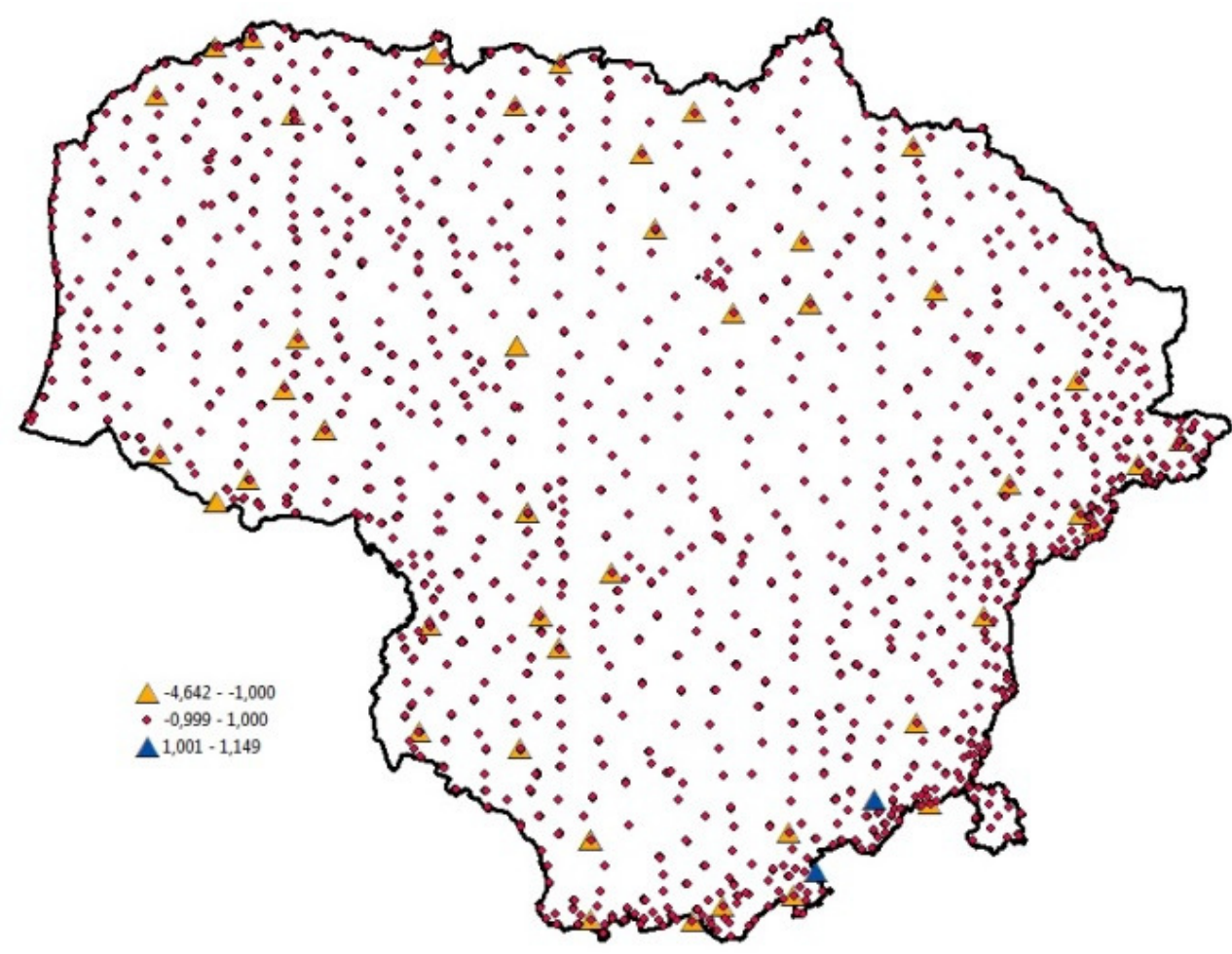

Fig. 7. Differences of normal heights at the ground control points (2 variant)

We could accept that gross errors are bigger than $1 \mathrm{~m}$. We could eliminate points containing the gross errors and calculate final statistical parameters (Fig. 8 and Fig. 9 and Table 2). 


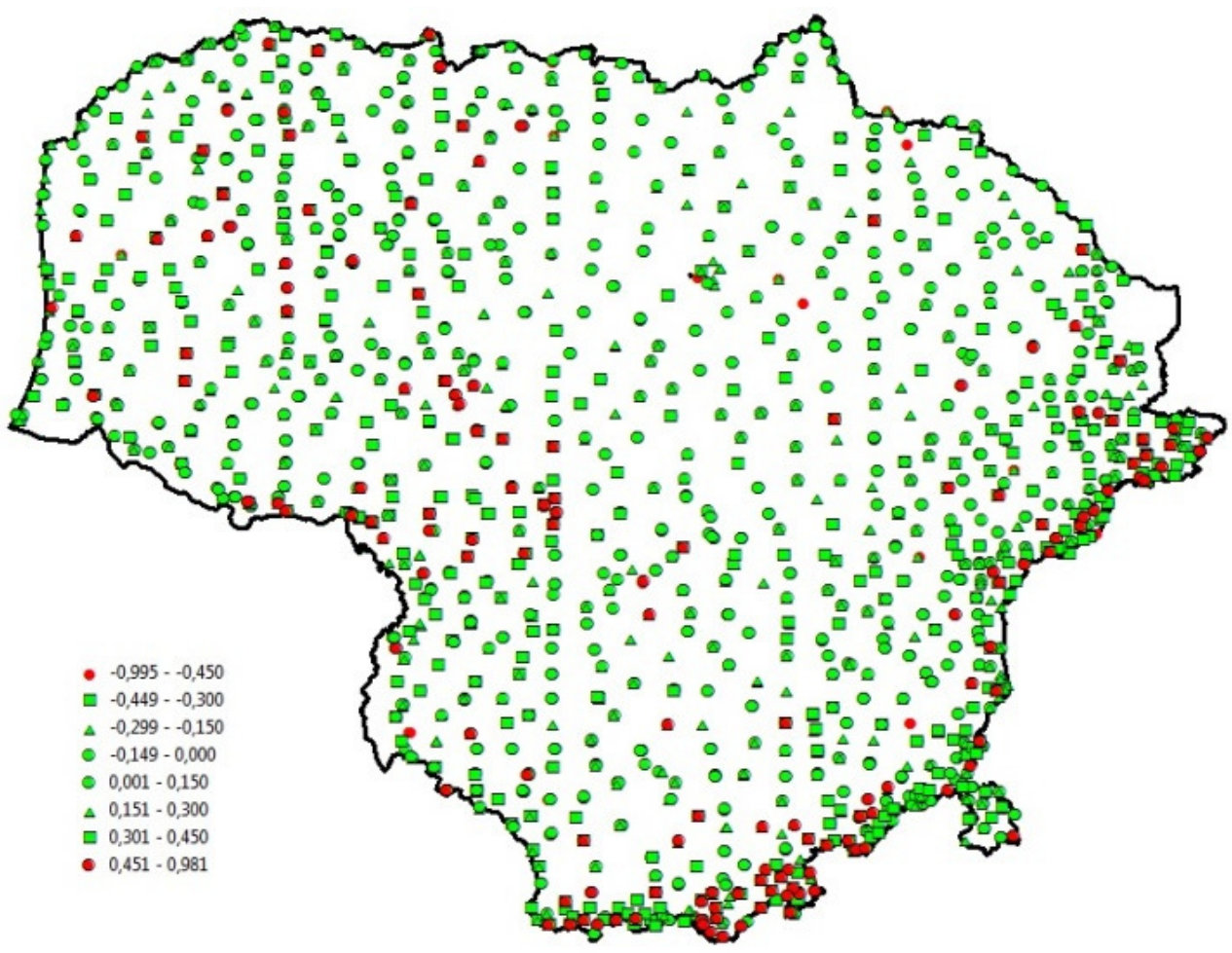

Fig. 8. Differences of normal heights at the ground control points after elimination of gross errors (1 variant)

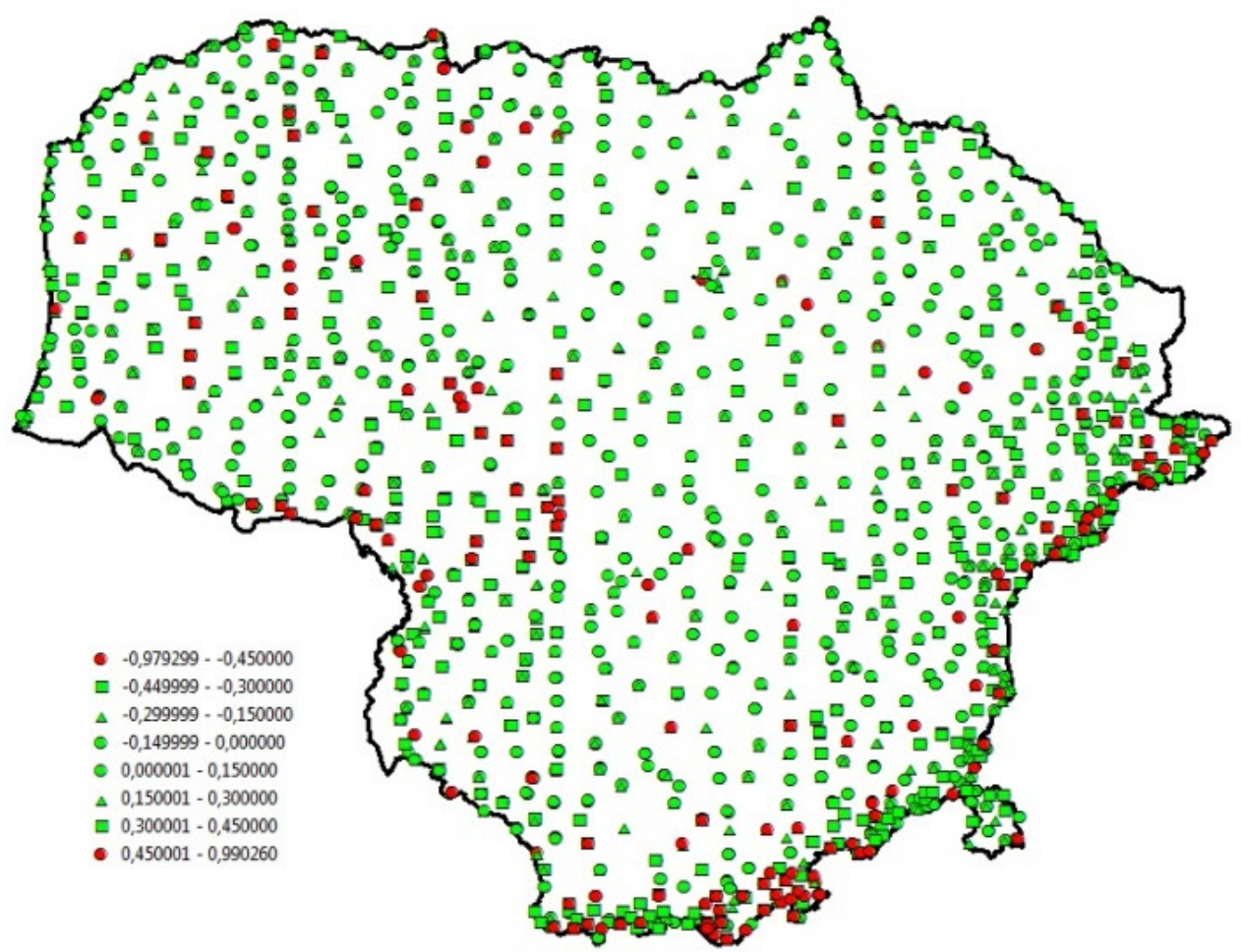

Fig. 9. Differences of normal heights at the ground control points after elimination of gross errors (2 variant) 
Table 2. DTM1 statistical parameters according to data of the ground control points

\begin{tabular}{lcc}
\hline Statistical parameter & $(1$ variant $)$ & $(2$ variant $)$ \\
\hline Mean, m & 0.094 & 0.095 \\
Standard Error, m & 0.005 & 0.005 \\
Median, m & 0.101 & 0.100 \\
Mode, m & 0.011 & 0.018 \\
Standard Deviation, m & 0.256 & 0.255 \\
Sample Variance, m & 0.066 & 0.065 \\
Kurtosis, m & 0.950 & 0.902 \\
Skewness, m & -0.399 & -0.360 \\
Range, m & 1.976 & 1.970 \\
Minimum, m & -0.995 & -0.979 \\
Maximum, m & 0.981 & 0.990 \\
Sum, m & 257.912 & 260.401 \\
Number of points & 2730 & 2728 \\
Confidence Level(95.0\%), m & 0.010 & 0.010 \\
\hline
\end{tabular}

\subsection{DTM1 evaluation against the normal heights of Lithuanian State GPS network points}

The normal heights of the Lithuanian State GPS network points were not corrected by distances, measured from the point mark till ground surface, because such kind of measurements were not acquired into database. That means that the evaluation of DTMs is not so reliable comparing to evaluation according to information of the vertical network or ground control points. Therefore the high density and good distribution of the GPS points create the satisfactory premises for the DTMs evaluation. The calculated differences of the ground truth normal heights and heights derived from DTM1 are presented in Figure 10 and Figure 11.

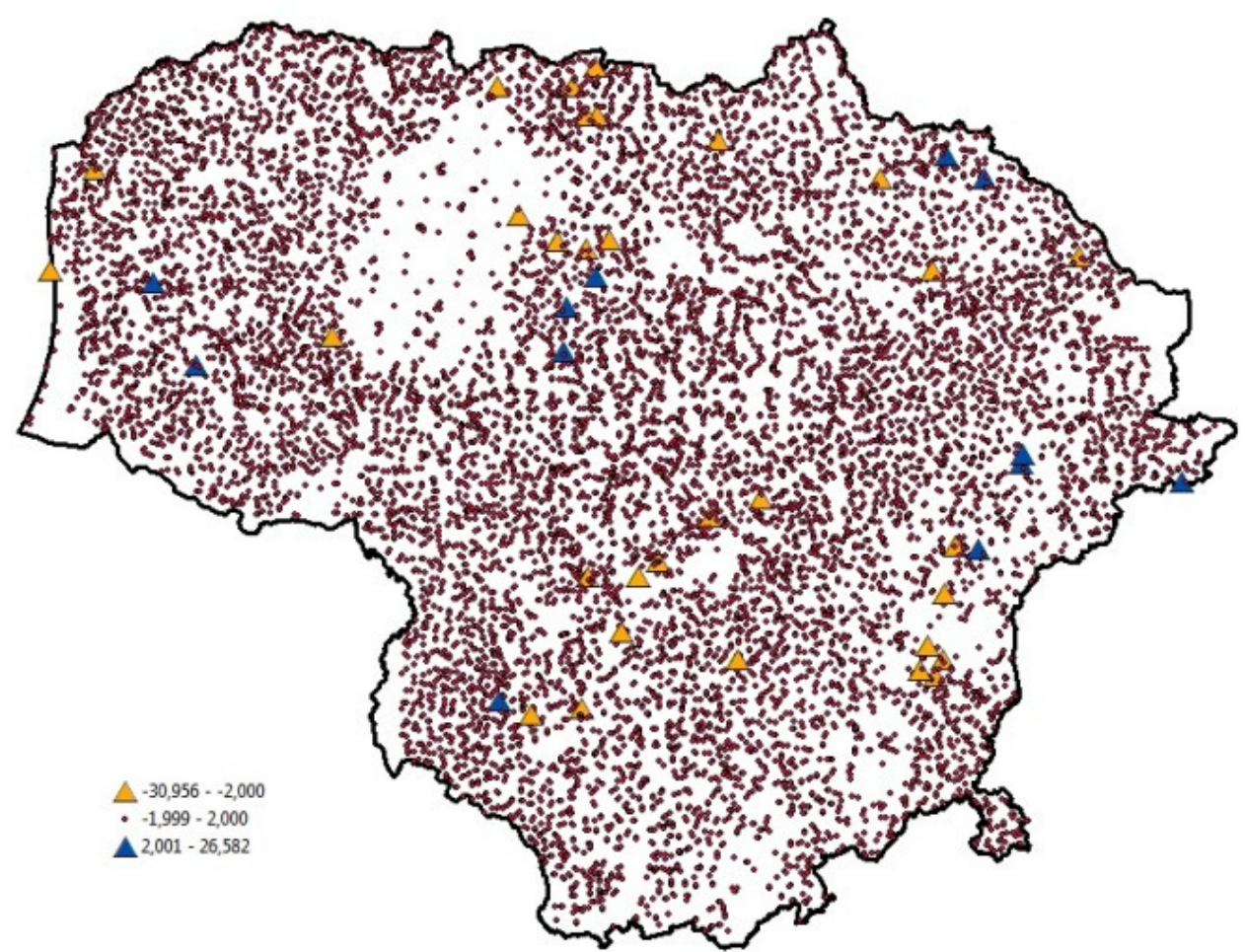

Fig. 10. Differences of normal heights at the Lithuanian State GPS network points (1 variant) 


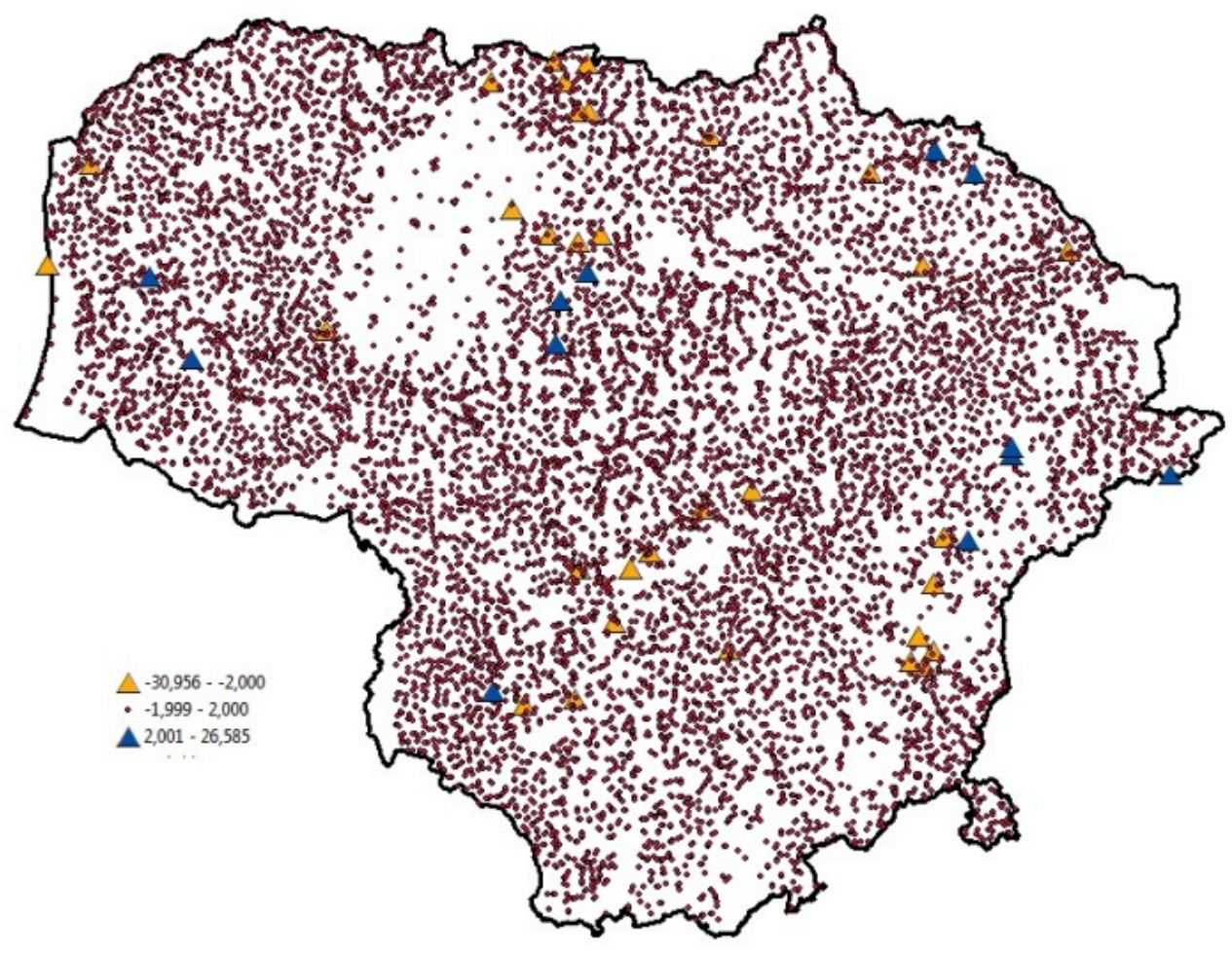

Fig. 11. Differences of normal heights at the Lithuanian State GPS network points (2 variant)

We could accept that gross errors are bigger than $2 \mathrm{~m}$. We could eliminate points containing the gross errors and calculate final statistical parameters (Fig. 12 and Fig. 13 and Table 3).

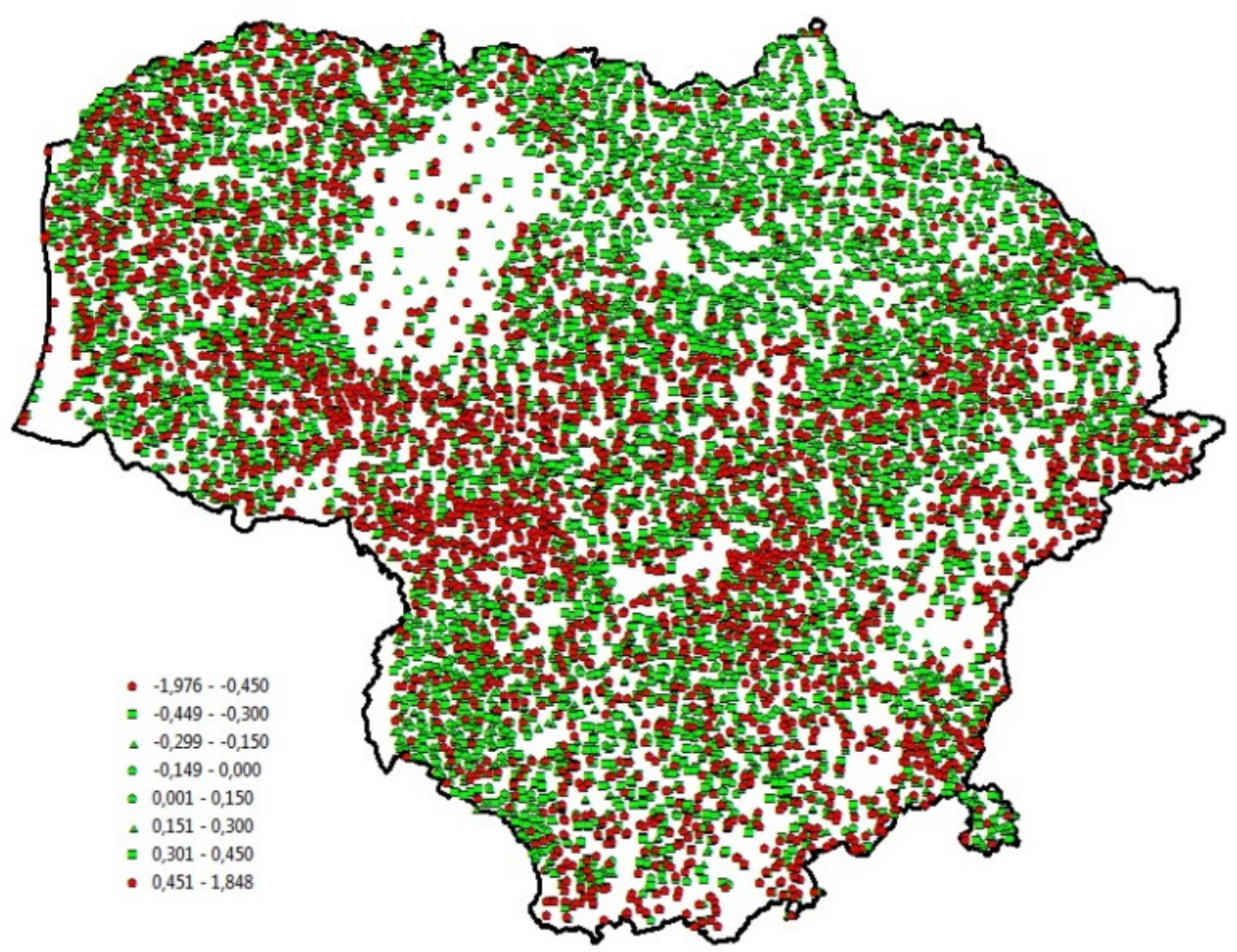

Fig. 12. Differences of normal heights at the Lithuanian State GPS network points after elimination of gross errors (1 variant) 


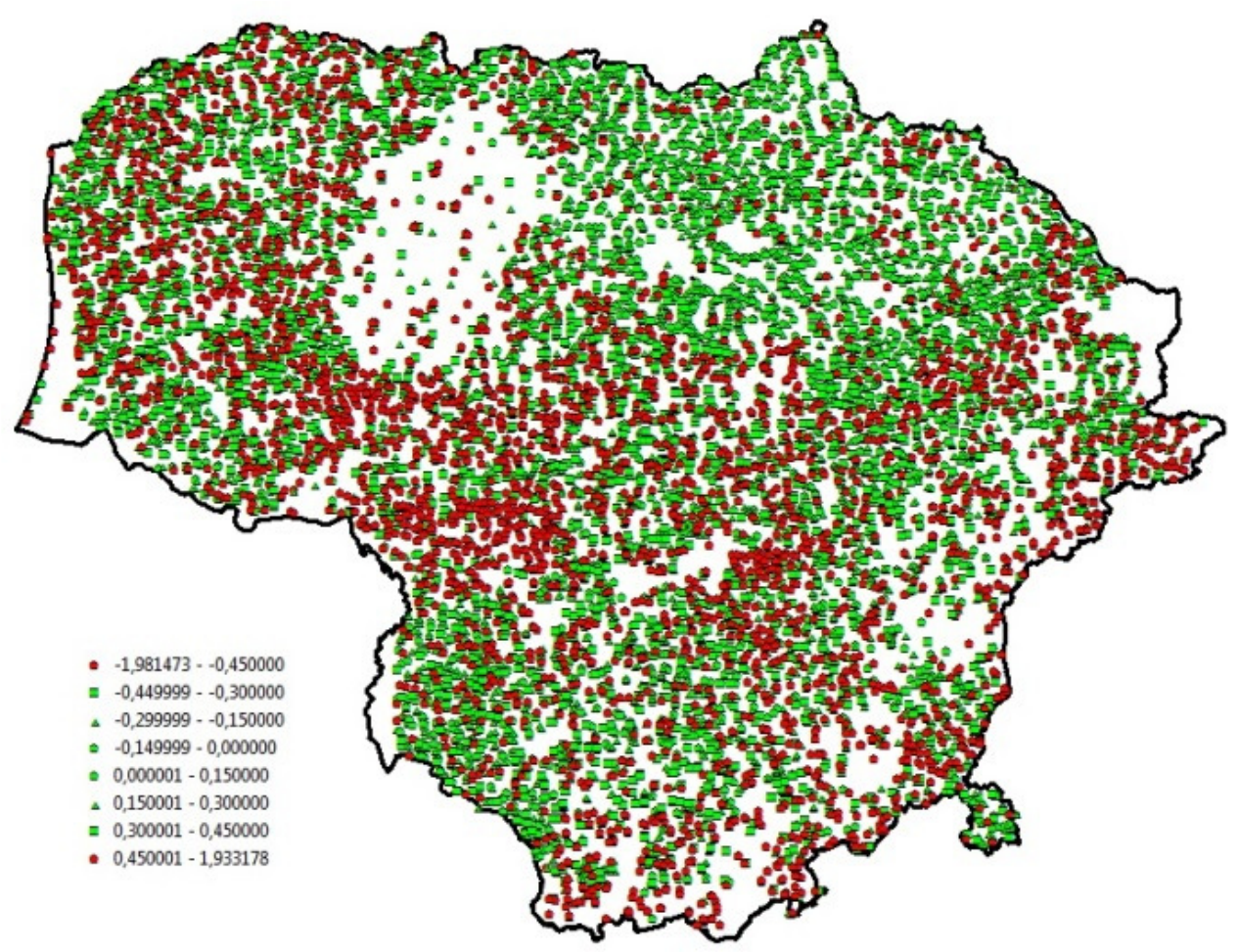

Fig. 13. Differences of normal heights at the Lithuanian State GPS network points after elimination of gross errors (2 variant)

Table 3. DTM1 statistical parameters according to data of the Lithuanian State GPS network points

\begin{tabular}{lcc}
\hline Statistical parameter & (1 variantas) & (2 variantas) \\
\hline Mean, $\mathrm{m}$ & 0.277 & 0.276 \\
Standard Error, $\mathrm{m}$ & 0.003 & 0.003 \\
Median, $\mathrm{m}$ & 0.292 & 0.290 \\
Mode, $\mathrm{m}$ & 0.405 & 0.246 \\
Standard Deviation, $\mathrm{m}$ & 0.344 & 0.341 \\
Sample Variance, $\mathrm{m}$ & 0.119 & 0.116 \\
Kurtosis, m & 3.626 & 3.559 \\
Skewness, $\mathrm{m}$ & -0.751 & -0.716 \\
Range, $\mathrm{m}$ & 3.824 & 3.915 \\
Minimum, m & -1.976 & -1.981 \\
Maximum, m & 1.848 & 1.933 \\
Sum, m & 3024.042 & 3013.652 \\
Number of points & 10926 & 10925 \\
Confidence Level(95.0\%), m & 0.006 & 0.006 \\
\hline
\end{tabular}

\section{Conclusions}

1. The vertical accuracy of DTM $1 \times 1 \mathrm{~m}$ resolution, which is based on LiDAR data, was investigated. The three data sets of geodetic data were used: the Lithuanian first and second order geodetic vertical network points; the ground control points of orthophotomapping of Lithuanian territory; the Lithuanian State GPS network points. Accordingly the standard deviations of the height component were found to be $0.50 \mathrm{~m}, 0.25 \mathrm{~m}$ and $0.34 \mathrm{~m}$.

2. It should be stated that some gross errors were eliminated from the vertical accuracy estimation procedure. These errors may limit DTM suitability for certain applications. The currently available DTM should be improved by data cleaning. 


\section{References}

[1] Jacobsen, K. 2004. Analysis of Digital Elevation Models Based on Space Information. EARSeL Dubrovnik. 8 p

[2] Kumetaitis, A. 2004. Skaitmeninio reljefo modelio sudarymas ir tobulinimas geostatistiniais metodais, Geodesy and Chartography 30(1): 29-34

[3] Marti, U. 2004. Comparison of SRTM data with the national DTMs of Switzerland. Paper presented at GGSM 2004 IAG International Symposium Porto, Portugal.

[4] Estornell, J.; Ruiz, L. A.; Velaszquez-Mart1, B.; Hermosilla, T. 2011. Analysis of the factors affecting LiDAR DTM accuracy in a steep shrub area, International Journal of Digital Earth 4(6): 521-538. http://dx.doi.org/10.1080/17538947.2010.533201

[5] Hirt, C.; Filmer, M. S.; Featherstone, W. E. Comparison and validation of the recent freely-available ASTER-GDEM verl, SRTM ver4.1 and GEODATA DEM-9S ver3 digital elevation models over Australia, 23 p. (draft)

[6] Schickler, W.; Thorpe, A. 2001. Surface estimatios based on LIDAR, in Proceeding of the ASPRS Annual Conference. St. Louis, Missouri, April. 11p.

[7] Stankevičius, Ž.; Kalantaite, A. 2009. LIDAR žemès paviršiaus taškų masyvo supaprastinimo algoritmų parametrų parinkimas, Geodesy and Cartography 35(2): 44-49. http://dx.doi.org/10.3846/1392-1541.2009.35.44-49

[8] Žalnierukas, A.; Čypas, K. 2006. Žemès skenavimo lazeriu iš orlaivio technologijos analizè, Geodesy and Chartography 32(4): $101-105$.

[9] Žalnierukas, A.; Ruzgienè, B.; Kalantaitè, A.; Valaitienè, R. 2009. Miestų skenavimo LIDAR metodu tikslumo analizè, Geodesy and Cartography 35(2): 55-60. http://dx.doi.org/10.3846/1392-1541.2009.35.55-60

[10] Hyyppä, J.; Hyyppä, H.; Leckie, D.; Gougeon, F.; Yu X.; Maltamo M. 2008. Review of methods of small-footprint airborne laser scanning for extracting forest inventory data in boreal forests, International Journal of Remote Sensing 29: 1339-1366. http://dx.doi.org/10.1080/01431160701736489

[11] Pereira, L.; Janssen, L. 1999. Suitability of laser data for DTM generation: a case study in the context of road planning and design, ISPRS Journal of Photogrammetry and Remote Sensing 54: 244-253. http://dx.doi.org/10.1016/S0924-2716(99)00018-0

[12] Reutebuch, S.; McGaughey, R.; Andersen, H. E.; Carson, W. 2003. Accuracy of a high-resolution LiDAR terrain model under a conifer forest canopy, Canadian Journal of Remote Sensing 29(5): 527-535. http://dx.doi.org/10.5589/m03-022 